\title{
Emerging Reality in Customary Land Tenure: The Case of Kachenga Village in Balaka District, Southern Malawi.
}

\author{
Paul Kishindo \\ Chancellor College, University of Malawi, Zomba \\ E-mail:paulkishindo@yahoo.co.uk \\ pkishindo@chanco.unima.mw.
}

\begin{abstract}
This paper discusses land tenure changes that have occurred in one village in Balaka district, southern Malawi and the forces that have been at work. The current land tenure system departs in a number significant of ways from what is supposed to be the ideal situation. Among the important changes are the diminishing role of the group village headman as allocator of land rights, increasing importance of family heads as allocaters of land rights and the development of an informal land market.
\end{abstract}

\section{Introduction}

Land is a source of food, employment and export earnings for many African countries. Apart from its economic importance, land also has a significant social value. Some sites are regarded as sacred and are treated with great respect as they may be associated with important events in the society's history, for example, its purported origins. Ultimately land provides a site where one will be buried at the end of one's earthly life.

Agriculture is the principal source of livelihood in Malawi. Almost 90 percent of all households can be labeled farming households (Republic of Malawi and World Bank, 2007:44). In most of the country's ethnic groups it is a customary requirement that one be buried among one's own kin regardless of where the death occurred; only then would the soul of the departed rest in peace. Identification with a village is therefore very important to most Malawians and it is reinforced by ownership of a house or crop field.

Human societies develop rules that define the way their members hold or own land, the rights that accrue from such ownership or holding and the obligations that arise there from. These rules in effect regulate the relationship of members of the particular society to their land, and they are enforceable in a formal court of law or customary structures. However, these rules do not remain static: they evolve to accommodate 
changed circumstances or are deliberately modified to suit stated government policies (see e.g. Quinlan 1983). The need to modernize agriculture has often necessitated modification of customary land tenures (Malawi Government 1967:399 - 409; Williams 1972). This paper discusses how current land holding practices and control over land in Kachenga village deviate from the norm in matrilineal social systems, and highlights the circumstances that underlie the changes. The data ${ }^{1}$ on which this paper is based was collected using formal and informal interviews. The group village head and village heads were interviewed to provide insights into customary land tenure. Further interviews were carried out with heads of households for insights into what was happening at the farm level. The first visits to the site were made in June 2005, but have continued since then as need for more data for the project arises. The site was chosen as a case study of a farming community in a matrilineal context.

\section{Kachenga Village}

Kachenga village in Balaka district, southern Malawi comprises 13 hamlets $^{2}$, with an estimated population of 1,500. It is headed by group village headman Kachenga who exercises his authority under chief Kalembo. ${ }^{3}$ The Yao, who are matrilineal, are the dominant ethnic group, constituting more than $90 \%$ of the population. Smallholder farming is the major occupation. Maize, cassava, cotton and sunflower are grown. Since the liberalization of burley tobacco production in 1996, a few households have been growing burley tobacco on their smallholdings.

According to the oral history of the village the first immigrants into the area were groups of matrilineally related kin of the Yao ethnic group under the leadership of Mpilisi Makochela. They arrived in 1951 from Chiunda, a place near Ulongwe in Balaka district which is the headquarters of chief Kalembo. The occupation of this previously uninhabited area was sanctioned by the chief to create a Yao buffer against the Ngoni of Ntcheu to the west. By allowing his subjects to occupy these uninhabited lands chief Kalembo was in effect extending the geographical limits of his authority, later recognized by the colonial authorities. Another view holds that chief Kalembo's authority over the area was already recognized by the colonial authorities and its occupation at this particular time simply confirmed the situation. The latter view seems to be the more correct because the District Administration (Natives) Ordinance of 1912, which created the office of native chiefs, demarcated the areas to be presided over by each chief (Mitchell, 1956:42).

On arrival in what was a large uninhabited area, the various matrilineages under their leaders were allowed to clear different parts of the area for settlement and farming. As a result of this arrangement matrilineages were associated with specific areas of the village, creating matrilineage - based hamlets which took on the names of their leaders. The 
earliest of these were Kachenga, Mizinga, Kimu, Chikamana and Mkalawile. Intragroup conflicts led to some members leaving to found new hamlets. These conflicts often arose as a result of competition among brothers for control of $\boldsymbol{m b u m b a ^ { 4 }}$. The $\mathbf{m b u m b a}$ are main vehicle for achieving social status among the matrilineal Yao (cf Mtika, 2002: 74). A number of the newer hamlets were born out of this competition. The old and new hamlets, however, still recognized the overall leadership of Mpilisi Makochela, who was formally recognized by the colonial authorities as a group village headman under chief Kalembo.

A succession dispute within the leading matrilineage in 1957 led to a split, with one section leaving to place themselves under chief Msamala in the same district. Chief Msamala allowed them to set up a hamlet called Mpilisi. The group that remained behind decided to adopt the name Kachenga for their leader, instead of the original Mpilisi, which was being claimed by the breakaway group. According to our sources Kachenga was actually the name by which the leaders of the immigrant group were known in Mozambique before they settled in Malawi. ${ }^{5}$

Over the years deliberate efforts were made by the group village headman to attract immigrants into the village. By encouraging immigration the group village headman enhanced his status among his peers; but it also meant a larger annual honorarium from government since this was reckoned on the basis of the number of poll tax payers in the village. Kandawire (1979: 101) noted that the Yao village headmen in Mozambique used land to build up followings on the basis of which they would lay claim to higher positions in the chieftaincy hierarchy. The practice was apparently imported into Malawi.

As the new land seekers and marital immigrants were not always Yao, the village now has within its population non - Yao members. Lomwe immigrants from the land pressure district of Chiradzulu constitute the largest minority group. They have a hamlet under their own leader on land allocated by the group village headman.

\section{Land Tenure Normative Practices}

Chief Kalembo is referred to as asyene chilambo in chiyao, meaning 'owner of the land'. The designation asyene chilambo does not in reality mean that the chief owns the land in the manner of a feudal landlord because the Yao, as is the case with the other ethnic groups in the country, believe land cannot be owned by any one person. His role is understood to be that of trustee and protector of the land on behalf of his subjects. This position of chiefs in relation to customary land is recognized in the Land Act 1965 which is currently in force.

The village headmen derive their authority from the chief who must formally recognize them upon selection according to custom. They form the access point to customary land. Land is viewed as a free good and is distributed primarily for food production and construction of a shelter. Allocations of land to outsiders are made by the group village headman and must be approved by the chief. The intention is to ensure that land does 
not pass to strangers to the disadvantage of legitimate claimants. Land disputes are in the first instance heard by village headmen. More complex cases are referred up the hierarchy to the chief. The chief also hears appeal cases from the village headmen's courts.

Women as 'owners' and 'builders of the village' are regarded as the primary right holders. The rights are intergenerationally transmitted from mother to daughter. A daughter is entitled to her own piece or pieces of land when she gets married or has her first child. These two events are taken to signify the attainment of adult status and independence from parental control. The piece of land will come from that share of land allocated to her mother. All daughters born to a woman, regardless of the circumstances of their birth, are entitled to a share of their mother's land. A woman's holding may be built up over time through transfers of land from older matrilineal kin, especially grandmothers, when they become too old to work the land, or die (cf Peters, 1997). Men enjoy secondary rights through the women they marry. They enjoy these rights for the duration of their marriages and survival of their wives (cf Peters 2010). Divorce or death of a wife effectively renders the uxorilocally married man landless as he has no independent claim to his wife's land. He must remarry to be able to gain access to land. His sisters or other matrilineal kin may allow him to use part of their own holdings while in - between marriages. The logic of the situation is that while a man needs a woman to gain access to land, a woman needs a man to perform what are regarded as 'male' tasks in the household such as building and maintaining a house, clearing land for cultivation, constructing the storage bins for the harvested crops and purchase of farm inputs such as fertilizer. The situation described here contrasts with Hilhorst's claim that women's rights in sub-Saharan Africa should be viewed as secondary rights obtained through husbands and male kin (Hilhorst 2000:182). Such a situation obtains in the patrilineal northern region where men have the primary land rights to land and pass them on to their sons. The inheritance system in the northern region effectively excludes women from inheriting land, on the assumption that women belong to their husband's village where they relocate on marriage.

The customary entitlement to land enjoyed by women in a matrilineal social system may work to the disadvantage of families with many daughters. A family with many daughters is likely to experience a decline in holding size faster than one with sons as the daughters must be accommodated while sons move out of the family to live in their wives' villages. The men have no claim on their mother's landholding, except where there are no female heirs.

Three distinct categories of land can be identified in the village: private land, common land and reserve land (see also von Benda - Beckmann 2007: 125) 
- Private land. This is land for the exclusive use of the family or individual to whom it is allocated. No person may enter or use it without the permission of the landholder. It is land recognized by the community as being used by that specific family or individual to the exclusion of others. The landholder may take measures to protect it against encroachment or trespass. Such measures include constructing a fence around it and the use of charms to keep away trespassers. Residential sites and crop fields are in this category. The rights to this land are transferable according to customary norms.

- Common land. This is land to which bona fide members of the village have the right of access. The village meeting ground, grazing grounds and burial grounds fall into this category. The group village headman may deny access to this land to the ineligible, and may regulate its use where necessary.

- Reserve land. This is in effect a 'store' from which further allocations of land can be made when needed. It consists of virgin bush and all land not already claimed by any of the matrilineages. It comes under the trusteeship of the group village headman. The group village headman may allocate some of this land to nonindigenous land seekers provided that future claims of the indigenous members of the village are not jeopardized. Leaders of matrilineages may make requests for some of this land on behalf of their kin when their own runs out. At the time of the study there was no virgin bush available for allocation to new claimants. The increase in population due to high birth rates and immigration has resulted in all good land being brought under cultivation.

\section{The Emerging Reality}

\section{Increased Perception of Ownership of Land}

While the matrilineages claim ownership of specific parts of the village, it is individual families within the matrilineage who work the land and make the every day decisions on it. These individual families have life time rights of use and occupation and view themselves as owners of the land (see also Nankumba and Machika 1988: 22). The claim of ownership is justified by reference to:

- Uninterrupted occupation and use over several generations.

- Allocations and reallocation of plots within the family without reference to an external authority

- The recognized right to exclude others from entering or using any part of the land 
- Recognition by other members of the village of the link between the family and the specific parcel of land.

The notion of another entity beyond the current family in occupation of the land as the real owners of the land appears fictive. Given this perception of ownership families claim the right to let out, give away, pledge and, as is becoming frequent, to sell part of their land. Primacy of settlement is often used by descendants of the original settlers to reinforce their claim to ownership of the land they occupy and use. Whenever land was required for a public purpose as was the case in the construction of the community day secondary school, nutrition rehabilitation centre and police post, the group village headman had to negotiate with individual families to release the land. The fact that the group village headman had to negotiate, rather than seize the land, serves to emphasize his limited authority over land that is already occupied and in current use.

\section{Informal Sales of Land}

Directly linked to the increased perception of ownership of land has been the development of an informal market for land. Land is sold informally in the village for the purpose of farming as well as for the creation of business structures. The World Bank (1987: 22) noted that the informal sales of customary land begun in the peri-urban areas where it was bought for building shops and houses but later spread to rural areas (see also Peters 2010: 188). Those that have bought land are people with ready cash either from business or wage employment; while those who sell are either poor families desperate for cash; or those who, for historical reasons, have more land than they need or can manage to cultivate. In all cases brought to our attention the sellers of land were linked to the group of early immigrants who claim primacy of settlement. Prices range from K2000 - K150006 per plot depending on size. What is actually paid, though, does not reflect the value of the land: rather it reflects the desperation of the seller and the bargaining ability of the buyer. In some cases existing personal relationship between the seller and buyer are taken into account in the transaction. The high mortality that the village has experienced in recent years has tended to free up some land for sale. This is sometimes done to pay off debts incurred during the illness of the deceased, or funeral expenses (cf Okuro, 2007: 113). An important observation to be made is that land is not sold to close relations: relatives tend to lend or give each other land. The group village headman is routinely called upon to act as witness to these sales. For being witness to these transactions, he receives a 'token of appreciation' in cash. The magnitude of the token depends on the price being paid, although there is no specific percentage attached. The highest so far received for this service was said to be K3000. Recent evidence suggests that what was originally meant to be a token has now become a fee which the group village headman demands for the service. 
The phenomenon of informal land sales has been observed in other districts as well (see e.g. Peters, 2010; Bosworth, 1997; Takane, 2005). Jul Larsen and Mvula (2009:185) in their study of land cases in southern Malawi observe that sales of customary land are a common phenomenon and that most traditional leaders have accepted the practice as a new element in customary land tenure. The question that arises is why the group village headman allows land sales when custom prohibits them. In his response the group village headman indicated that he cannot stop a family that wants to sell part of its land holding: he can only advise about the possible negative consequences of such action on future generations who might find themselves landless or land poor. The responsibility for preventing land passing on to non - kin was shifted to leaders of the matrilineages. The evidence, however, indicates that these leaders can be defied by determined land holders. Apparently while custom prohibited the sale of land compliance was achieved by moral pressure rather than by specific negative sanctions. Under the increased perception of ownership of land, as opposed to mere right of use, moral pressure seems inadequate to deter families who see possible benefits in the sale of land. It is also possible to suggest that the group village headman may be acquiescing in these sales because the 'token of appreciation' serves as an incentive. The fact that people now regard land as a saleable commodity is a reflection of the increasing monetization of the rural economy through its links with Balaka town and beyond. In the context of land scarcity and increasing demand landholders are imputing a monetary value to a resource that was traditionally believed to have no such value.

The development of an informal market for land means that families with access to financial resources can acquire additional land and build up holdings, or acquire land through purchase where customary arrangements prevented it; while at the same time, poorer families risk losing the most important social and economic resource that they have. In this development could lie the genesis of social stratification in the village as a few individuals with financial resources could potentially accumulate land for purposes other than subsistence production. There is already one such case of a businessman who had married into the village in the 1990s buying up land for commercial farming.

However, there is a potential risk in the land sales. They may be challenged subsequently by a member of the family needing land in the future. Jul - Larsen and Mvula (2009: 186) reported that in Thyolo district many of the cases that were brought before the magistrates' courts were related to land sales. Conflict arose either as a result of disagreement about a mandate to sell or regret on the part of the seller. Where the seller expressed regret at the sale the customary justice system normally allowed the seller to buy back the land. We recorded one case of a brother buying back land that had been sold by a sister because he felt the elder sister was jeopardizing her children's future. While there is a general acceptance that land can be sold there is a lingering desire to hold onto it apparently because it is the basic means of subsistence for the villagers. 


\section{Declining Allocatory Role of the Group Village Head}

Natural increase and increased immigration ensured the depletion of virgin bush that could be allocated to land seekers. This in effect means that the group village headman has no land under his direct authority which he can distribute to land seekers. Yet it is the control of access to land that distinguishes the group village headman from the commoner. The disappearance of reserve land has thus led to a decline in the group village headman's status, a situation that Bosworth (1997) also observed in his study of chief Kaomba's area in Kasungu district, in the central region.

In the absence of virgin bush for distribution land seekers now have to deal with individual families which have surplus land. Descendants of the original immigrants from Chiunda, who for historical reasons tend to have larger than average holdings, have become important allocators and sellers of land. The status of heads of families of these groups has risen while that of the group village headman correspondingly declines. In this new situation allegiance transfers from the group village headman to the giver of the land.

The group village headman has in an attempt to remain relevant in land distribution, made several attempts to assert his control over abandoned land, including that which properly belonged to members of the matrilineages. These efforts have been resisted. It was feared that the group village headman would either sell the land for his personal benefit, or give it to his own kin. The chief supported the position taken by lineage leaders that the land previously used by a member of a lineage reverted to the matrilineage and not the group village headman. This incident highlights the appellate role of chief Kalembo as asyene chilambo in land matters.

\section{Male occupation of land in maternal village}

While normatively there should not have been male members of the local matrilineages resident and cultivating land in their maternal village, our study found such cases. Investigations revealed that this is possible under the following conditions:

- Where there are no daughters to inherit a mother's land

- Where a family for historical or genealogical reasons, has more land than it needs or can manage to cultivate.

- Where female heirs are not able to cultivate all their land because of a shortage of family labour, or resources to hire it when it is not available within the family.

- Where the man is in - between marriages (see also Peters, 2010: 183) 
Where there are no female heirs to inherit a deceased mother's land, a man's security on lineal land is assured.It is not so assured when the man holding the land has sisters. Sisters are likely to reclaim land from their brother when their daughters or grand daughters need land. It appears that while men can be accommodated on land belonging to their matrilineage, such use can only be temporary. Peters (1997:205) in her study reports that serious disputes between brothers and sisters, or between maternal uncles and nieces arose which might compel men to relocate elsewhere. In these disputes uncles are often accused of witchcraft. The group village headman and lineage leaders confirmed that in disputes over land, customary law is in favour of women as men are essentially usurpers of their sisters' land rights. This view suggests that male presence in maternal villages is merely tolerated rather than accepted. Where the man is the sole inheritor of his mother's land, it is likely that the land would be passed on to his daughters, eventually re-establishing the mother-daughter inheritance pattern (see e.g. Peters, 2010: 185).

\section{Conclusion}

This paper has demonstrated that the land tenure system in Kachenga is undergoing some important changes. Land is increasingly accessed through local families who have more of it than they need. These are largely descendants of the earliest settlers in the village who claim ownership by primacy of settlement. The absence of unallocated land to distribute to new applicants reduces the status of the group village headman while correspondingly raising that of individual families with spare land. A new form of allegiance is created between the givers and receivers of land which excludes the group village headman.

The scarcity of land and monetization of the rural economy has led to the recognition of land as a saleable commodity, which in turn could be fuelling the assertion of ownership of land as opposed to mere right of use. The group village headman has been forced to accept the new reality and adapted to it by assuming the new role of witness to land transfers for which he receives a 'token of appreciation' in cash. The possibility of earning the 'token' could be an incentive to the group village headman for not preventing the transfer of land to non - kin. A new form of land acquisition based on the ability to purchase now coexists with that based on kinship and residence. The possibility for virilocal residence has also developed as men, under some circumstances, acquire and use land in their maternal, rather than their matrilineal villages.

From the changes that have been detailed in the paper it is apparent that land tenure is dynamic and capable of responding to demographic pressure and economic opportunity. The emerging practices and patterns of landholding have not been proclaimed by the chief or the group village headman but are manifest in practice. The subtle changes that are occurring at the village level are evidence that land tenure systems at any historical period must ultimately be understood as a product of many influences, both internal 
and external.

\section{Endnotes}

1. The study is part of a larger on-going study titled 'Agricultural Development in a Matrilineal Social System' in the Department of Sociology, Chancellor College, University of Malawi, led by the author .

2. A hamlet is called musi (chi yao for village). The larger entity is called by the same name. Hamlet leaders are officially known as village headmen. The group village headman title signifies the office holder's authority over these smaller entities. As used here, the title is gender neutral.

3. The official designation is Traditional Authority (TA). The lowest level of the chiefly hierarchy is village headman (woman); the next level is group village headman then sub - traditional authority (STA). Above the TA is a new creation, Senior Chief; and then Paramount chief. Paramount Chiefs (of whom there are seven) do not deal directly with land matters.

4. A mbumba is a group of sisters and their children under the guardianship of an elder brother. Anthropologists view it as the smallest matrilineal group or 'effective minimal lineage'. A mbumba is a potential basis for political position among matrilineal people as women are regarded as the 'builders of a village'.

5. The Yao began to migrate into Malawi from Mozambique in the early 1860s. They came as hunters and traders.

6. At the time of the study 1 US dollar = MK146.00 